\section{Sodium content and neutralising capacity of some commonly used antacids}

Patients suffering from hepatic failure, renal failure, and occasionally heart failure may require treatment regimens needing strict control of sodium intake. The incidence of dyspeptic symptoms in these conditions is high so that they are frequently treated concomitantly with antacids. Some antacids contain large quantities of sodium,,$^{12}$ sufficient to complicate seriously any therapeutic regimen requiring salt restriction.

Information on the theoretical sodium content of $B P$ and $B P C$ preparations is readily available, but only one proprietary antacid preparation states the sodium content on its statutory product data sheet. To make this information freely available, we have measured the sodium content of 15 liquid and 13 tablet antacids which are in common use in our health district. The neutralising capacity of each antacid was also measured so that a comparison of in vitro neutralising capacity and sodium content can be made.

\section{Methods and results}

Neutralising capacity was measured by a modification of the method of Fordtran et al..$^{3}$ Sodium content was measured by flame photometry. The results are shown in the table as a mean of at least three estimations.

Sodium content and neutralising capacity of some commonly used antacids

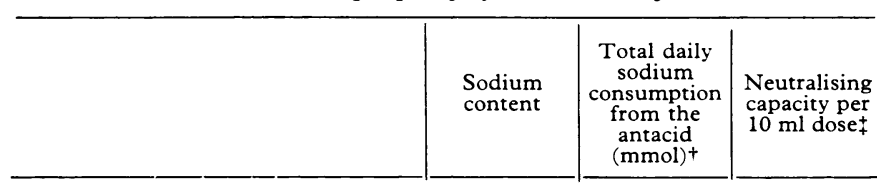

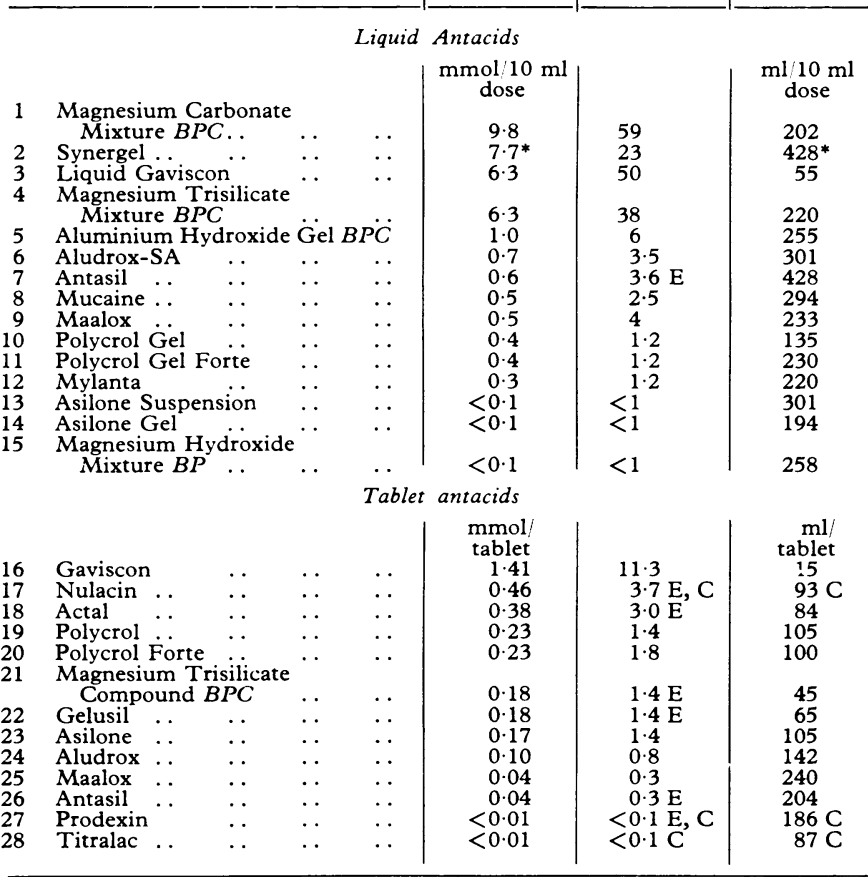

* Result expressed per sachet since this preparation is presented in single dose *Result expressed per sachet since this preparation is presented in single dose
sachet $(20 \mathrm{~g}$, approx $15 \mathrm{ml})$ and the physical properties are such as to make accurate pachet $(20 \mathrm{~g}$, approx

+Total daily consumption of sodium calculated from manufacturer's maximum recommended dose.

+ Neutralising capacity $=$ millilitres of $0.1 \mathrm{~N} \mathrm{HCl}$ neutralised in vitro in $2 \mathrm{~h}$ at $37^{\circ} \mathrm{C}$ by $10 \mathrm{ml}$ liquid antacid or 1 tablet at stirring rate $120 \mathrm{rpm}$

= Contains calcium as active ingredient.

$\mathrm{E}=$ Estimated; where no upper dose limit is recommended, consumption is estimated on basis of three $20-\mathrm{ml}$ doses of liquid antacid, or, for tablet antacids, eight tablets per day. Calculations for $B P C$ preparations are similarly based.

\section{Comment}

Patients with hepatic or renal failure frequently require dietary sodium restriction to maintain fluid balance. Most such dietary regimens limit sodium consumption to about $40 \mathrm{mmol}$ per day, but it is occasionally necessary to reduce this to $20 \mathrm{mmol}$ per day.
Some antacids (see table, 1-4 and 16) contain such large amounts of sodium that the sodium consumed from that source would soon exceed the daily allowance of a $40 \mathrm{mmol} /$ day regimen. Note that Synergel contains a significantly greater concentration of sodium than Liquid Gaviscon, but the manufacturer's maximum recommended dosage for their product is different, so that the daily sodium consumption from Liquid Gaviscon is more than twice that from Synergel. This factor may be of importance for tablet antacids, where, although the total sodium content per tablet is usually small in comparison with liquid antacids, the manufacturers frequently fail to indicate an upper limit on the number to be consumed (E).

The neutralising capacity of different antacids varies widely. Although Synergel contains a very high sodium concentration, it at least has the potential advantage of a high neutralising capacitywhereas Liquid Gaviscon (also high sodium) has a tiny neutralising capacity.

For some liquid preparations (see table, 5-12) sodium salts are present in chemically significant amounts as contaminants of the active ingredients, which may themselves have been prepared from other sodium salts. There is no designated limit of impurity with respect to sodium. Nevertheless, our results indicate that this contamination is present in quantities small enough to be clinically insignificant except if consumed in unusual quantities by patients on the strictest salt-free regimens.

${ }^{1}$ Bleifer, K H, Belsky, J L, and Bleifer, D J, New England fournal of Medicine, 1959, 261, 604.

2 Rimer, D G, and Frankland, M, fournal of the American Medical Association, 1960, 173, 995.

${ }^{3}$ Fordtran, J S, Morawski, S G, and Richardson, C T, New England fournal of Medicine, 1973, 288, 923.

(Accepted 18 October 1977)

Department of medicine, University of Bristol

R E BARRY, MD, MRCP, lecturer in medicine

J FORD, laboratory technician

\section{Familial hypercholesterolaemia with alpha ${ }_{1}$-antitrypsin deficiency}

$\alpha_{1}$-Antitrypsin deficiency (PiZZ) has been recorded in association with pulmonary emphysema ${ }^{1}$ and juvenile liver cirrhosis ${ }^{2}$ but not with genetically determined conditions. We report a patient with familial hypercholesterolaemia associated with obstructive lung disease with $\alpha_{1}$-antitrypsin deficiency PiZZ. Such an association has not been described.

\section{Case report}

A 54-year-old man presented with the sudden onset of hemiparesis and aphasia, which recovered progressively. For 15 years he had had chronic bronchitis, emphysema, and severe progressive exertional dyspnoea. At the age of 34 he had been told that his serum cholesterol concentration was raised and he had been treated initially with a diet and latterly with cholestyramine. Three years before admission he had had renal colic and a stone had been shown on intravenous pyelography. His father and his three brothers had all died suddenly in their 20 s from an illness characterised by precordial pain, while both of his paternal aunts had died from cerebral thrombosis, one in her 20s, the other in her 50s. Examination showed many xanthelasmas, corneal arcus, and several xanthomas on both Achilles tendons. The thyroid was not palpable. The chest was barrel shaped, hyperresonant on percussion, with prolonged expiration and widespread rhonchi. A slightly tender liver was felt $2 \mathrm{~cm}$ below costal margin. Peripheral pulses were palpable, and the optic fundus showed arteriovenous nipping and slight arterial narrowing.

Investigations showed: haemoglobin $17.9 \mathrm{~g} / \mathrm{dl}$, packed cell volume $56.8 \%$, normal liver function tests, albumin $40.6 \mathrm{~g} / 1, \alpha_{1}$-globulin $0.7 \mathrm{~g} / 1, \alpha_{2}$-globulin $10.5 \mathrm{~g} / \mathrm{l}, \beta$-globulin $8.0 \mathrm{~g} / \mathrm{l}, \gamma$-globulin $9.8 \mathrm{~g} / \mathrm{l}$, urate $0.24 \mathrm{mmol} / 1(4.1 \mathrm{mg} / 100$ $\mathrm{ml})$, cholesterol $8.66 \mathrm{mmol} / 1\left(377 \mathrm{mg} / 100^{\circ} \mathrm{ml}\right)$, triglycerides $1.13 \mathrm{mmol} / 1$ $(100 \mathrm{mg} / \mathrm{ml})$. The results of determinations in 1955 had been: cholesterol $15.64 \mathrm{mmol} / 1(610 \mathrm{mg} / 100 \mathrm{ml})$, and in 1976: cholesterol $12.30 \mathrm{mmol} / \mathrm{l}$ $(480 \mathrm{mg} / 100 \mathrm{ml})$, triglycerides $0.89 \mathrm{mmol} / 1(79 \mathrm{mg} / 100 \mathrm{ml})$.

Lipoproteinogram: $\alpha$-lipoprotein $23,4 \%$, pre- $\beta$ - plus $\beta$-lipoproteins $76,6 \%$. Very prominent pre- $\beta$-lipoprotein with normal triglycerides was interpreted as a "sinking pre- $\beta$." $\mathrm{Po}_{2}$ was $5.8 \mathrm{kPa}(43.3 \mathrm{~mm} \mathrm{Hg}), \mathrm{PCO}_{2} 4.9 \mathrm{kPa}$ 